\title{
Beelde vir die kruis van Christus in die vierde en vyfde eeu
}

\author{
H F Stander \\ Departement Antieke Tale \\ Universiteit van Pretoria
}

\begin{abstract}
Images of Christ's cross in the $4^{\text {th }}$ and $5^{\text {th }}$ centuries

The Church Fathers did not have a common theory or system of atonement. Therefore, if one wants to appreciate what they had to say about atonement, one needs to study the rich images that pervade their literature. Their beliefs concerning atonement were not expressed in words, but in symbols, especially of the cross. This article discusses the various symbols of the cross of Christ which are to be found in the writings of theologians of the $4^{\text {th }}$ and $5^{\text {th }}$ centuries. Reijners (1965) has undertaken an exhaustive study of the images of the cross in the first three centuries, but the writings of the fourth and fifth centuries have never been scrutinized for these images.
\end{abstract}

\section{INLEIDING}

Young $(1987,1997)$ het alreeds aangetoon dat die tema van verlossing in die vroegChristelike geskrifte baie selde behoorlik aangespreek word, omdat feitlik al die studies tot dusver deur sogenaamde "retrospektiewe historici" aangepak is. Daarmee bedoel sy dat telkens wanneer 'n dogmatiese leerstuk by die kerkvaders nagevors word, dit gedoen word met die oogmerk om "spore" of "bewyse" te kry van een of ander denkskool wat eers later ontwikkel het. Die navorsers slaag dus nie daarin om regtig insig te verkry in die antieke teoloë se verlossingsleer nie.

Dit feit van die saak is dat ons nie moet probeer om die kerkvaders se verlossingsleer sistematies te ondersoek en te kategoriseer nie. Young stel dit duidelik dat as 'n mens wil verstaan wat die kerkvaders oor die verlossing geleer het, 'n mens moet 
begin om hulle ryk tipologie en allegorie, asook die veelkantigheid van hulle beelde, te waardeer. Sodra jy egter probeer om 'n sistematiese teologie op te stel, en 'n ryk beeld êrens in daardie sisteem in te pas, is jy dadelik besig met 'n skeefgetrekte teorie.

Young (1997:147) sê verder dat die kerkvaders beelde gebruik het deur bloot aardse en sigbare realiteite simbolies te interpreteer om na hemelse realiteite te verwys. So kan 'n mens byvoorbeeld iets van die kerkvaders se verlossingsleer begryp deur net 'n katalogus saam te stel vir die beeldryke name wat vir Christus gebruik is. 'n Mens dink aan woorde soos Deur, Weg, Lam, Klip, Pêrel, Sout, Blom, Lig, Aarde, Wurm, Mosterdsaad, ensovoorts. Ook Reijners (1973) skryf dat 'n mens nooit vir enige konsekwente en ontwikkelde verlossingsleer by die vroeg-Christelike outeurs moet gaan soek nie. Hulle verlossingsleer is in simbole en uitgebreide metafore, en nie in woorde nie, uitgedruk. Wanneer hulle oor die verlossing praat, het hulle dikwels juis hulle toevlug geneem tot simbole vir die kruis van Jesus.

As 'n mens dus regtig 'n smaak wil ontwikkel vir die antieke teoloë se leer oor die verlossing, moet ' $n$ mens probeer om die rykdom van die beelde wat hiervoor gebruik is, te waardeer sonder om enigsins verder ' $\mathrm{n}$ teorie daar rondom te probeer bou. Dit is dan ook wat die doelstelling van hierdie artikel is, naamlik om die beelde wat vir die kruis van Jesus gebruik is, te beskryf. Dit sal ons ook insig gee in die antieke teoloë se verlossingsleer.

In hierdie artikel sal daar slegs gekyk word na beelde wat kerkvaders in die $4 \mathrm{e}$ en 5e eeu gebruik het vir die kruis van Christus. Die rede daarvoor is dat Reijners (1965, 1973) reeds 'n omvattende studie gedoen het oor die simboliek van die kruis in die eerste 3 eeue. Daar bestaan egter geen studie oor die kruissimboliek in die 4e en 5e eeu nie, terwyl daar juis 'n merkwaardige verskuiwing plaasgevind het rakende die visuele voorstelling van die kruis in hierdie eeue, soos ons later sal sien. Die doel van hierdie artikel is dus om die hedendaagse leser in te lei in die rykdom van die beelde wat die antieke skrywers gebruik het om uitdrukking te gee aan hulle verlossingsleer. Omdat daar vir ons so 'n groot skat van Chrysostomos se preke behoue gebly het, is dit natuurlik vanselfsprekend dat die meeste voorbeelde juis ook uit sy preekversameling kom. 


\section{VAN SKANDE TOT EER}

Om aan 'n kruis te gesterf het, was 'n groot skande. Daarom ook dat ons lees dat Christus se sterwe aan die kruis 'n vernederende dood was (Fil 2:8). Ook Heb 12:2 verwys na die skande wat met 'n kruisdood geassosieer is. Maar die kerkvaders het verskeie kere hulle verbasing uitgespreek oor die feit dat dit wat eens 'n simbool van skande was, so gou verander het in 'n simbool van eer vir beide vooraanstaande en die mees gewone mense (Podskalsky 1991:549). Chrysostomos (De cruce et latrone, PG 49, p-399) skryf dat alhoewel die kruis anvanklik gesien is as die simbool van veroordeling, dit algou verander het tot 'n eervolle simbool van God se verlossingsplan. Asterius (Hom 8) sê ook dat alhoewel die kruis anvanklik 'n simbool van skande was, dit nou 'n simbool van oorwinning geword het. Athanasius (Athanasius, Quaestiones in scripturam sacram) reken dat die kruis van Jesus met eer en heerlikheid geassosieer word, aangesien dit ontelbare goeie dinge bewerkstellig. Dit vernietig onder andere die dood, en neem ook ons sonde weg.

Volgens Chrysostomos (Pater, si possibile est, transeat PG 51:35) is die kruis helderder as die son, en ook meer glansend as die strale daarvan. Wanneer die son verduister word, kan 'n mens die son nie meer sien nie, maar dan word dit steeds oortref deur die glans van die kruis. Talle ander kerkvaders besing die kruis as simbool van die opstanding van die dode, en sê dat dit hoop bied vir hulle wat sonder hoop is, vertroosting vir hulle wat arm is, rus vir hulle wat swaar kry, en vryheid vir slawe. Dit is ook 'n wet vir die wetteloses, die sekuriteit van die wêreld, en die krag van die magteloses.

\section{TIPOLOGIE}

Die vroeg-Christelike skrywers het die Ou Testament en die heidense geskrifte abselutt noukeurig gefynkam vir heenwysings na die kruis van Christus (Finney 1997). Hulle het vooraf-skaduwings van die kruis gesien in Jakob se leer en in die koperslang op die paal, en so ook in Odysseus wat aan 'n skeepsmas vasgemaak was. Chrysostomos sê dat die staf van Moses ook 'n tipe was van die kruis van Jesus. Soos die staf van Moses die rots oopgekloof het, so kloof die kruis van Jesus weer die harte van mense oop (De adoratione pretiosae crucis, PG 52:839). Voorts sien hy 'n prototipe van die kruis in Aäron en Hur wat Moses se hande omhoog gehou het (Synopsis scripturae sacrae, PG 56:327). Volgens Proclus (Hom, 22.3) kan 'n mens die kruis van Jesus ook in die 
doringbos sien waarin die ram vasgehaak het toe Abraham vir Isak wou offer. Soos die doringbos die ram vasgehou het, so het die kruis Jesus "vasgehou".

Kerkvaders het ook dikwels die kruis van Jesus vergelyk met die boom in die paradys (Severianus van Gabala, In incarnationem Domini, 445ff). Hulle kon hierdie

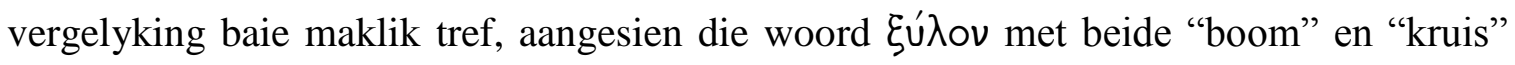
vertaal kon word. Chrysostomos (De sancto hieromartyre Phoca, PG:702) wys dan daarop dat die hout van die boom in die paradys groen en vars was, tog het dit die dood gebaar. Die hout van die kruis daarenteen, was droog en dor, tog het dit lewe voortgebring. Athanasius (Quaestiones ad Antiochum ducem) sê dat die vrug wat die boom in die paradys gedra het, sonde was, terwyl die vrug wat die kruis gedra het, redding vir die mens is. Verder het die antieke teoloë die kruis van Christus gesien in allerhande menslike voorwerpe, soos in die dwarshoute van 'n leer, en in die skering en inslag van 'n weefstoel. Kom ons kyk dus nou vervolgens na die verskillende beelde wat vir die kruis van Jesus gebruik is:

\section{MILITÊRE BEELDE}

\subsection{Trofee (тро́таıоv)}

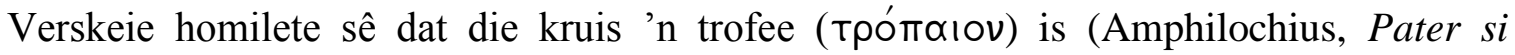

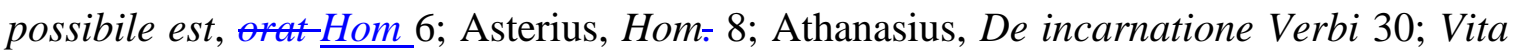
sanctae Syncleticae; Chrysostomos, De coemeterio et de cruce, PG 49:396; Gregorius Nazianzenus, In sanctum pascha, salutare Pascha). Wanneer soldate 'n vyandige mag verslaan het, het hulle laasgenoemde se skilde, helms, en ander wapentuig teen 'n boom opgehang, of aan 'n paal vasgemaak. Dit is 'n trofee (тро́таıоv) genoem, en het gedien as 'n teken of bewys dat hulle die vyand ' $n$ verpletterende neerlaag toegedien het. Wanneer die kruis ingeplant is, lyk dit nes die paal waaraan die vyand se eiendom opgehang is. Maar nou is dit nie skilde en helms wat daaraan hang nie, maar wel Jesus Christus.

Chrysostomos sê die kruis van Jesus het nou 'n trofee geword as bewys dat die demone vernederend verslaan is. Hy sê elders (In sancta et magna parasceue, PG 50:811; In venerabilem crucem sermo, PG 50:819) dat die kruis ' $n$ trofee is want dit jaag die demone weg. Gewoonlik het die skilde op so 'n trofee geblink in die son. Ook die 
kruis van Jesus was as trofee glansend blink en kon van oral af gesien word (Chrysostomos, In Matthaeum, PG 57:24). Die kruis was nie net 'n trofee nie, maar ook

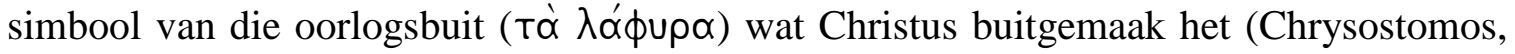
In Matthaeum, PG 57:24; Eclogae PG 63:821).

\subsection{Swaard ( $(\xi i ́ \phi \circ)$}

Volgens Chrysostomos (De coemeterio et de cruce, PG 49:396) is die kruis ook 'n swaard ( $\xi^{\prime}$ 'фos). Dit is nie moeilik om te sien waarom die kruis die antieke skrywers aan 'n swaard laat dink het nie: Die lang vertikale deel van die kruis verteenwoordig die lem, terwyl die boonste deel van die kruis die handvatsel van die swaard simboliseer. Die kruis word ook 'n swaard waarmee Christus ons sonde doodgemaak het.

\subsection{Groot swaard (}

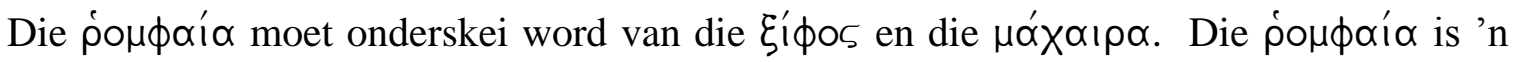

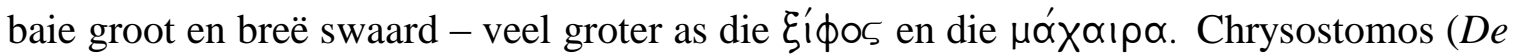

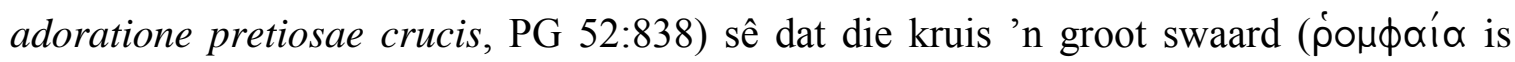
waarmee die duiwel verslaan word.

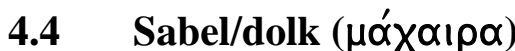

Langs die swaard se skede, is 'n $\mu \alpha^{\prime} \chi \alpha ı \rho \propto$ (sabel/dolk) gedra. 'n Mens kan dit as 'n groot mes, of ' $\mathrm{n}$ kort swaard (of dolk) beskryf. Chrysostomos (De coemeterio et de cruce, PG 49, p. 396) sê dat Christus se kruis 'n dolk is waarmee Hy die slang (= Satan) deurboor het.

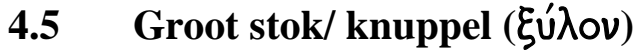

Die $\xi u ́ \lambda$ ov was 'n groot stok of knuppel waarmee iets of iemand geslaan kon word. Die kruis is so 'n groot stok of knuppel ( $\xi u ́ \lambda$ ov) waarmee die werke van die Satan vernietig word (Chrysostomos, De adoratione pretiosae crucis, PG 52:838).

\subsection{Muur (}

In tyd van oorlog is 'n sterk verdedigingsmuur en 'n goeie wapen onontbeerlik. Dit bied

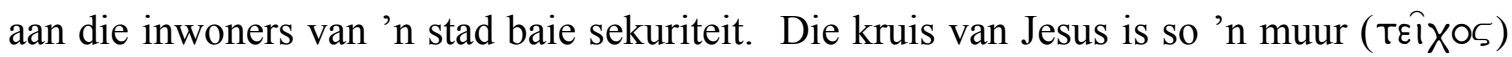


waardeur die vyand nie kan breek nie, en dit is ook 'n wapen (öா $\lambda \circ \mathrm{v}$ ) wat nog nooit oorwin is nie. Ryk mense kan by hierdie kruis veiligheid kom opsoek, maar die kruis is terselfdertyd ook rykdom vir arm mense. Dit neem 'n mens se negatiewe emosies weg, en help jou om deugde te verkry. (Chrysostomos, Pater, si possibile est, transeat PG 51:35; Sien ook Proclus, Hom. 29.3.13; 29.5.26). Elders (In venerabilem crucem sermo, PG 50:819) sê Chrysostomos dat die kruis van Christus 'n muur ( тદ̂ંХ૦૬) is vir mense wat in geestelike stryd is.

\subsection{Wapenuitrusting ( $\pi \alpha \nu \circ \pi \lambda i ́ \alpha)$}

Christus se volgelinge word ook sy soldate genoem. Maar Christus rus sy soldate nie toe met 'n gewone wapenuitrusting soos 'n boog of skild of helm nie, maar met sy kruis. En hierdie kruis word die totale wapenuitrusting van Jesus se volgelinge. Dit word tegelykertyd 'n swaard, 'n skild, 'n borsplaat, 'n helm, 'n beenbeskerming, 'n skuilplek, 'n oorwinningskroon. Chrysostomos sê dat die kruis van Christus tegelykertyd al hierdie dinge is, want 'n gelowige moet al dié toerusting gebruik wanneer hy/sy die Satan wil verslaan (Chrysostomos, De adoratione pretiosae crucis, PG 52:837).

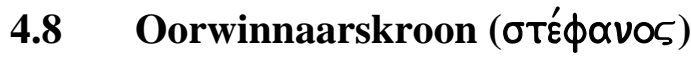

Wanneer die antieke mens op die sportveld of die slagveld oorwin het, het hy 'n oorwinnaarskroon verkry. En Jesus se kruis is presies dit, naamlik 'n oorwinnaarskroon (Chrysostomos, De confessione pretiosae crucis, PG 52:841).

\section{LANDELIKE LEWE}

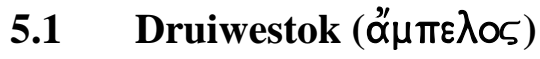

Die kruis is ook 'n druiwestok, omrede Christus, die ware druiwestok, daaraan vasgemaak is (Chrysostomos, Collegerunt Judaei, PG 59:526). So verkry ons die

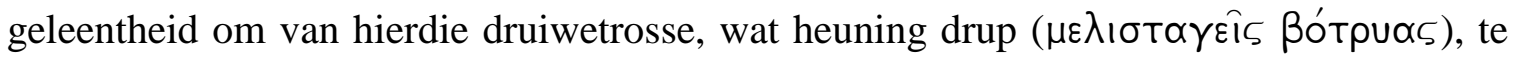
kan eet. Chrysostomos sê verder dat ons ons redding verkry wanneer Christus ons help om druiwestokke ( $\left.\alpha^{v} \propto \delta \varepsilon v \delta \rho \alpha ́ \delta \propto \varsigma\right)$ te word wat teen hierdie druiweboom oprank. 


\subsection{Boom ( $\left.\delta^{\prime} \varepsilon \delta \rho \rho o v\right)$}

Maar Chrysostomos sê dat die kruis ook 'n gewone boom ( $\left.\delta^{\prime} \varepsilon \delta \rho \rho \nu\right)$ is. Toe Jesus aan die kruis was, het hy met die water wat uit sy sy gekom het, die wortels van hierdie boom natgemaak. Die wortels kon in die grond gaan, en die takke kon na die hemel uitsprei. Die blare van hierdie boom bly vars en nuut, en die blom daarvan verlep ook nooit. Daarom dat hierdie boom ewige vrug dra, naamlik onsterflikheid (In parabolam de ficu, PG 59:590). Die kruis word dus self ook 'n onsterflike boom genoem (Chrysostomos, In adorationem venerandae crucis, PG 62:750).

\subsection{Wingerdstut ( $\chi \alpha ́ \rho \alpha \xi)$}

Athanasius (Disputatio contra Arium) beskryf die kruis as 'n stut ( $\chi \propto \alpha \rho \xi \xi)$ waarmee 'n wingerdstok regop gehou word. Hy verduidelik dat Christus, die ware wynstok op hierdie stut hang.

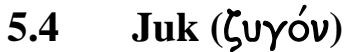

In 'n baie interessante geskrif verduidelik Chrysostomos dat Paulus en Petrus eintlik vergelyk kan word met 2 osse wat saamgejuk was in een juk. Die kruis van Christus is 'n juk, en daarom het hierdie twee apostels die kruis as juk opgeneem. Die diere se koppe

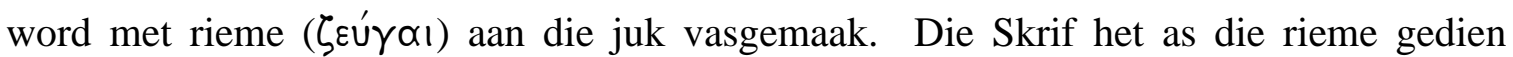
waarmee Paulus en Petrus aan die kruis vasgejuk was. Diere word met 'n lat (К'́vтроv) aangejaag. Maar Paulus en Petrus is deur die genade van die Heilige Gees voortgedryf in hulle taak ( In Petrum et Paulum, PG 59:493).

\subsection{Hamer ( $\sigma \phi \hat{p} \rho \alpha)$}

Hesychius (Hom-iv.1) gebruik pragtige beelde om die Paasgebeure te beskryf. Hy sê dat Jesus se kruis (= sy sterwe) 'n hamer ( $\sigma \phi \hat{u} \rho \alpha)$ is, en dat sy opstanding die aambeeld (ök $\mu \omega v)$ is. Daarmee sê Hesychius dat hierdie twee gebeure onafskeidbaar deel uitmaak van mekaar. Verder gebruik 'n mens 'n hamer en aambeeld as jy 'n trompet ( $\left.\sigma \alpha{ }^{\prime} \lambda \pi ı \gamma \xi\right)$ wil maak. En met hierdie koninklike en geestelike trompet word die Goeie Nuus oor Jesus se sterwe en opstanding verkondig. Dit is interessant dat nadat Hesychius 'n klomp beelde gebruik het om die Paasgebeure te beskryf, hy duidelik uitspel dat hy geen woorde het om die grootheid van dit alles te besing nie. Daarom volstaan hy ook met hierdie 
beelde. Dit is eintlik presies wat Young gesê het, naamlik dat ons net die kerkvaders se beelde moet geniet, sonder om vir hulle 'n sistematiese teologie op te stel.

\subsection{Sweep $(\mu \alpha ́ \alpha \sigma i \xi)$}

Met 'n sweep $(\mu \alpha \dot{\sigma} \sigma \tau \xi \xi)$ het jy perde geslaan, of ook kriminele gegésel. Volgens Chrysostomos is die kruis van Jesus so 'n sweep $\left(\mu \alpha \alpha_{\sigma \tau} \mid \xi\right)$ want daarmee kan 'n mens enige demoon wat sy opwagting maak, verdryf. (De adoratione pretiosae crucis, PG $52: 838)$.

\subsection{Horing ( $k \varepsilon ́ \rho \propto \varsigma)$}

Soos 'n horing regop op die kop van 'n dier staan, so het die kruis ook regop op Golgotha gestaan. En 'n horing was simbool van sterkte. Net so was ook die kruis vir die kerk 'n simbool van krag. Daarmee word die vyand omvergegooi, en die gelowiges gered. Chrysostomos sê dus dat 'n mens die kruis die horing van die kerk kan noem, omrede dit die krag van die kerk is (De adoratione pretiosae crucis, PG 52:836).

\subsection{Fontein (}

Maar 'n mens kan die kruis ook 'n fontein ( $п \eta \gamma \eta)$ noem omrede dit 'n lafenis bied vir mense wat geestelik dors is (Chrysostomos, In venerabilem crucem sermo, PG 50:819).

\section{SEEVAART}

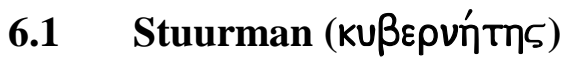

Elke gelowige is besig om in die bootjie van die lewe te vaar. Chrysostomos (In venerabilem crucem sermo, PG 50:819) sê dat die kruis van Christus die stuurman

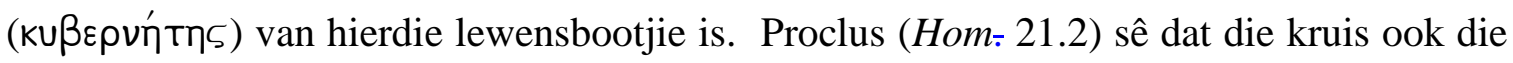
roer is wat gelowiges lei na die hemelse hawe.

\subsection{Hawe $\left(\lambda_{\iota \mu \eta ́}\right)$}

Gelowiges wat in hulle lewensbootjie vaar, word dikwels deur die storms van die lewe geteister. Maar gelukkig ondervind hulle wat in sulke storms vasgevang word, baie gou 
dat die kruis van Christus vir hulle 'n veilige hawe ( $\left.\lambda_{ı} \mu \eta^{\prime} v\right)$ is (Chrysostomos, In venerabilem crucem sermo, PG 50:819).

\subsection{Skeepsmas ('lotós)}

Die kruis is ook die mas (ioTós) van 'n boot. 'n Mens maak seile aan hierdie mas vas. Christus was aan die kruis vasgemaak, en daarom is Christus ook die seile van hierdie boot. Geloof is jou anker, en die tou waarmee jy die boot vasmaak, is hoop. Gebed is die roeispaan, en korrekte leringe is die roerpen van die boot. Die briesie wat die boot voortstu, is die Heilige Gees, en die Vader van die heelal is ons stuurman (Amphilochius,

De recens baptizatis, orat Chrysostomos, De jejunio, PG 60:716; Quod mari similis sit haec vita PG 64:22).

\section{GODSDIENSTIGE LEWE}

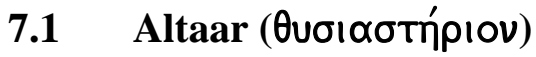

Christus het gesterf ter versoening van ons sondes. Sy kruis het as die altaar (Avoıøotńpıov) gedien (Chrysostomos, De cruce et latrone, PG 49:400). Maar Chrysostomos sê dat hierdie altaar eintlik baie vreemd was, want die priester wat die offer gebring het, was Christus self. Tog was Christus nie net die offerande nie, maar tegelykertyd ook die priester. Elders (De cruce et latrone, PG 49:408) sê Chrysostomos dat Christus na die vlees die offerande was, maar na die Gees was Hy die priester.

\section{STAATKUNDIGE LEWE}

\subsection{Koning ( $\beta \alpha \sigma \backslash \lambda \varepsilon u ́ s)$}

Wanneer Chrysostomos na die kruis kyk, sien hy 'n koning wat daar uittroon. Hy sê dat die kruis simbool is van 'n koninklike amp (De cruce et latrone, PG 49:403), want hy sien ook 'n koning wat gekruisig is. Net soos 'n herder sy lewe aflê vir sy skape, net so is 'n koning bereid om sy lewe af te lê vir die mense wat Hy regeer. Daarom noem Chrysostomos die kruis 'n koning. 


\section{HUISHOUDELIKE LEWE}

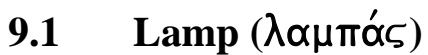

Chrysostomos verduidelik dat 'n mens 'n lamp aansteek, en dit dan regop plaas sodat dit die donkerte uit die huis verdryf (De coemeterio et de cruce, PG 49:397). Hy sê dit is

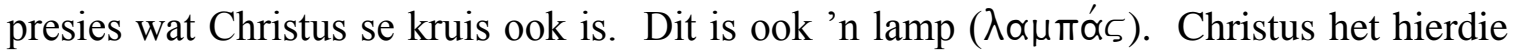
lamp aangesteek en dit regop geplaas sodat dit die donkerte uit die wêreld kan verdryf. Elders (In venerabilem crucem sermo, PG 50:819) sê hy dat die kruis die lig ( $\phi \hat{\omega}$ ) is vir hulle wat in die duisternis sit. Die kruis is ook 'n lig wat demone en enige ander dwaling verdryf (De cruce et latrone, 18). Maar op 'n ander plek redeneer Chrysostomos egter weer dat die kruis 'n lampstaander ( $\left.\lambda u x v^{\prime} \alpha\right)$ is, omdat Christus self die lig is (In drachmam et in illud: Homo quidam habebat duos filios, PG 61:781; In adorationem venerandae crucis, PG 62:747). Ook Hesychius (Hom- Hom: iii,2895 gebruik dieselfde beeld en noem die kruis 'n $\lambda$ úxvos.

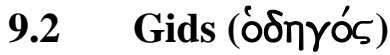

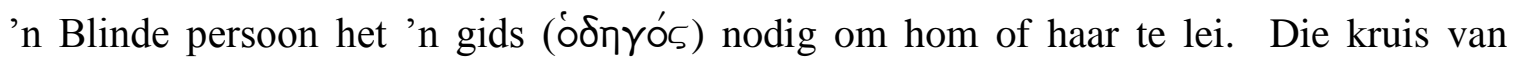
Christus is so 'n gids wat mense wat in duisternis verkeer, die weg moet wys (Chrysostomos, In venerabilem crucem sermo, PG 50:819).

\subsection{Staf ( $\rho \alpha ́ \beta \delta \circ \%)$}

Moses het 'n staf ( $\rho \alpha ́ \beta \delta o \varsigma)$ gehad, waarmee hy die see oopgekloof het en God se krag aangetoon het. Vir die apostels was die kruis van Jesus 'n staf ( $\rho \alpha ́ \beta \delta o s)$ waarmee hulle oor die hele wêreld heen gegaan het, en ook groot wonders gedoen het (Chrysostomos, Expositiones in Psalmos, PG 55:269).

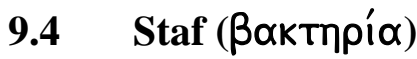

Mense wat lam is, het 'n staf of kierie nodig. Net so dien die kruis van Christus as 'n kierie of staf vir diegene wat geestelik lam is (Chrysostomos, In venerabilem crucem sermo, PG 50:819). Elders (Precatio PG 64:1068) sê Chrysostomos dat die kruis soos die staf van 'n herder is, waarmee Christus ons op veilige paaie lei. Amphilochius (De 
recens baptizatis, erat. Hom 7) sê dat die kruis 'n herderstaf is waarmee verdwaalde skape weer op die regte pad gebring word. Met hierdie herderstaf word tegelykertyd ook die leeu, die aartsvyand van die skape, doodgemaak. Hiermee sinspeel Amphilochius op Christus se oorwinning oor die satan.

\subsection{Leer $(k \lambda \hat{i} \mu \alpha \xi)$}

Die kruis is vir ons 'n leer $(\kappa \lambda \hat{\imath} \mu \propto \xi)$. Christus het teen hierdie leer opgeklim en sy hande uitgestrek en vir ons op so 'n wyse 'n pad gemaak waarmee ons kan opklim van die aarde tot in die hemel (Chrysostomos, in In parabolam de ficu, PG 59:590).

\subsection{Visstok (ká $\lambda \alpha \mu \circ \varsigma)$}

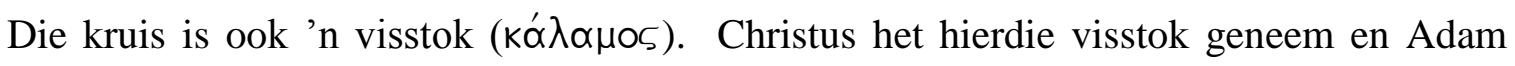

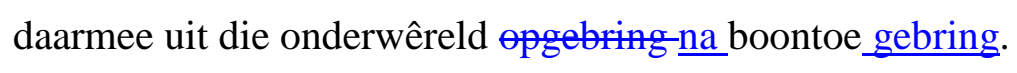

\subsection{Grendel ( $\mu \circ \times \lambda$ ós $^{2}$}

'n Gelowige moet altyd waak oor dit wat hy of sy sê. 'n Mens moet 'n deur voor jou mond plaas, en daarby ook 'n grendel waarmee jy daardie deur toehou. As grendel

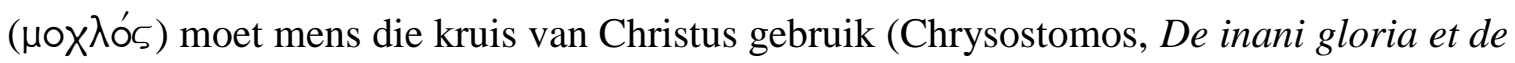
educandis liberis, 384).

\subsection{Bruidskamer (}

Amphilochius (De recens baptizatis, orat 7) sê dat die kruis ook 'n bruidskamer (табто́s) is. 'n Bruid en 'n bruidegom kom in 'n bruidskamer bymekaar, en so word kinders verwek. In hierdie bruidskamer is 'n nuwe volk verwek. Die een dag nog was dit net ' $n$ bruidskamer, en die volgende dag is 'n nuwe volk gebore.

\subsection{Beskermer/Oppasser ( $\pi \alpha ı \delta \alpha \gamma \omega \gamma o ́ s)$}

Die antieke kind is oral deur 'n slaaf of oppasser vergesel. Net so is ook die kruis van Christus ons beskermer en oppasser ( $\pi \propto, \delta \alpha \gamma \omega \gamma o ́ s)$ (Chrysostomos, In venerabilem crucem sermo, PG 50:819). 


\subsection{Brood (’’pто5)}

Die kruis is brood (äpros) vir hulle wat honger is (Chrysostomos, In venerabilem crucem sermo, PG 50:819). Daarmee sê Chrysostomos dat die verlossing wat Christus bied, die geestelike honger van mense stil.

\subsection{Bedekking/beskerming ( $\left.\sigma \kappa^{\prime} \operatorname{\pi \eta }\right)$}

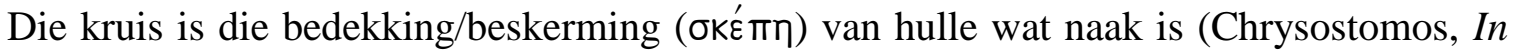
venerabilem crucem sermo, PG 50:819). Kerkvaders het dikwels aangetoon dat die naakte Jesus ons naaktheid bedek het. Proclus sê juis dat die kruis 'n skêr was wat Christus naak gemaak het. Barkhuizen (2001b:25) skryf dat "the image of the scissors of the cross emphasises the violent character of the act of the killing". Dit is egter waarskynlik nie die fokus van hierdie beeld nie. Dit is meer waarskynlik dat Proclus met hierdie beeld sê dat soos wat 'n skêr gebruik is om skape te skeer en hulle nakend te maak, so het die kruis ook Jesus ontbloot. Maar deur Jesus se naaktheid, is die mens beklee met dit wat onverganklik is (Proclus, hom $\underline{H o m}$ - 29:1.3).

\section{VOORSTELLINGS VAN DIE KRUIS IN DIE KUNS}

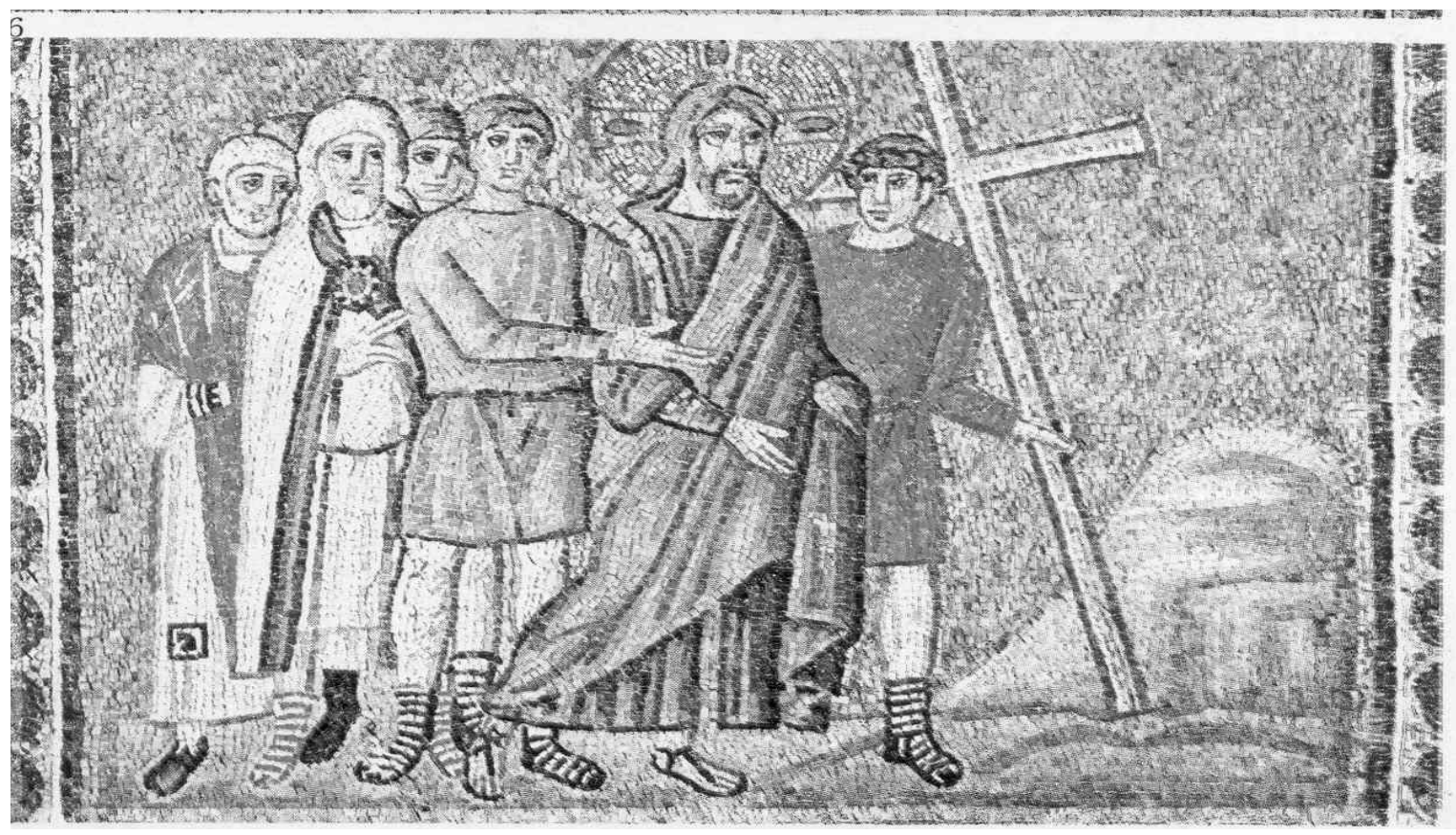

Fig 1: Simon van Ciréne-Siréne dra die kruis van Jesus. Dit is 'n tengerige kruis waaraan 'n mens nie juis vasgespyker kan word nie. Op so 'n manier onderstreep die kunstenaar Jesus se oorwinning oor die dood. (S. Apollinare Nuovo, Ravenna). 


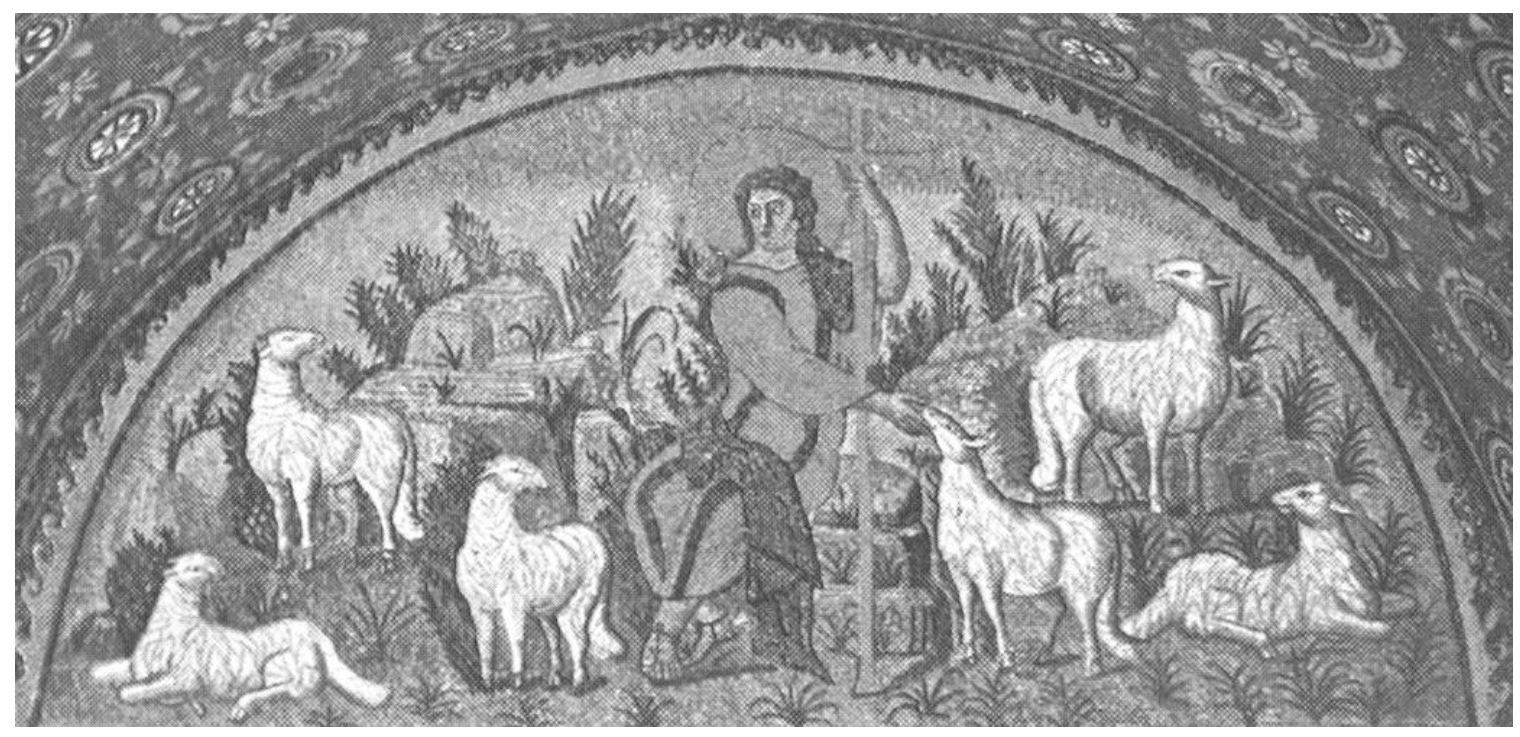

Fig 2: Jesus word hier onmiskenbaar as die Goeie Herder uitgebeeld. 'n Herder se klere is gewoonlik eenvoudig, maar Jesus word hier met 'n koninklike gewaad uitgebeeld. Die herderstaf is ' $n$ kruis. Hierdie is geen groot en growwe kruis nie, en boesem dus ook nie vrees in nie. Die kruis wat tot 'n herderstaf omvorm is, beeld dus weer Jesus se oorwinning oor die kruis uit. (Galla Placidia, Ravenna).

Soos wat die kruis in die letterkunde 'n simbool van oorwinning geword het, eerder as 'n simbool van skande, so het dit ook in die vroeg-Christelike kuns 'n eervolle simbool geword. In die voor-Konstantynse tyd is die kruis egter nooit as simbool in die kuns gebruik nie. Die oudste argeologiese voorbeeld wat ons het van die kruissimboliek is Konstantyn se gebruik van die labarum (Finney 1997). Daar is verskeie redes waarom die kruis nie in die eerste 3 eeue as simbool buite die literêre wêreld gefunksioneer het nie. In die eerste plek het die eerste Christene weggeskram daarvan om die kruis as simbool te gebruik, omrede die heidene die kruis so verkeerd verstaan het. Die kruis het dieselfde negatiewe assosiasie gehad, as wat die galg in ons tyd het. Voorts is die Christene swaar vervolg in die eerste 3 eeue na Christus. Die eerste Christene het dus verkies om eerder op Christus se oorwinning oor die dood te fokus, as om te herinner te word aan die lyding van hulle "Leier".

In die vierde eeu, nadat die Christendom as staatsgodsdiens aanvaar is, het die Christene egter vir die eerste keer begin om die kruisiging van Jesus uit te beeld. Maar dit is eers vanaf die Bisantynse periode, en veral vanaf die Middeleeue, dat ons 
voorstellings begin kry van 'n bloedige kruisiging, van Jesus wat aan 'n groot en harde en growwe kruis ly en baie smart verduur. Voor hierdie tydvak, in die 4e-6e eeu, is die kruis elke keer as 'n onskadelike werktuig in Jesus se hande uitgebeeld. So sien ons byvoorbeeld in figuur 1 waar Simon van Siréne die kruis van Christus dra. Maar dit is 'n dun en onskadelike ou kruisie waarteen die mense beslis nie vir Jesus sou kon vasspyker nie. Op so 'n manier wys die kunstenaar dat Jesus oor hierdie kruis $(=$ dood) triomfeer het.

In fig 2 sien ons waar Jesus as 'n Goeie Herder uitgebeeld word. In sy hand hou Hy 'n kruis, maar dit is weer eens 'n onskadelike kruis. Trouens, die kruis is hier niks anders as 'n herderstaf nie. En op hierdie wyse toon die kunstenaar aan dat Jesus geheel en al oor die kruis getriomfeer het. Die kruis kon niks teen Christus vermag nie.

Die kruissimboliek wat ons hier in die kuns sien, korreleer dus presies met dit wat ons oor die kruis lees in die geskrifte van die kerkvaders van die 4e en 5e eeu. Die beelde wat hulle vir die kruis gebruik, onderstreep telkens die feit dat Jesus oor die kruis triomfeer het.

\section{SLOT}

Bogenoemde beelde vir die kruis is gerangskik volgens die velde waaruit dit geneem is. Maar dit kan hoegenaamd in geen teologiese sisteem rakende die verlossing ingepas word nie. As 'n mens reg wil laat geskied aan die kerkvaders, kan 'n mens hoogstens 'n katalogus van hierdie beelde maak, en dit geniet vir wat dit probeer sê. Die beelde oor Jesus se kruis is ryk, en skenk aan ons 'n insae in die kerkvaders se verlossingsleer.

As 'n mens kyk na al die beelde wat die antieke teoloë gebruik het om vir hulle lesers te wys wat die kruis van Jesus alles beteken, kan 'n mens dadelik begryp waarom Chrysostomos (Ad eos qui scandalizati sunt, 17) ook gesê het dat die kruis die bewys is van die grootste Voorsienigheid en van die goedheid en van die liefde van God. Hy sê verder dit is die fondament $\left(\theta \varepsilon \mu \varepsilon^{\prime} \lambda{ }_{10}\right)$ van die kerk, maar ook die fondament van ons

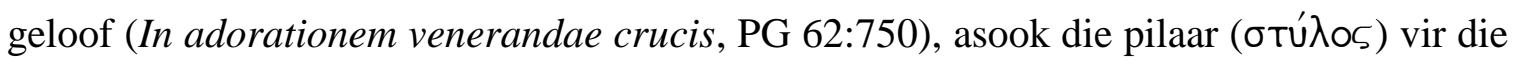
gelowiges (In venerabilem crucem sermo, PG 50:819). Geen wonder nie dat die antieke teoloë verklaar het dat "die teken van die Seun van die mens wat met die wederkoms in 
die hemelruim sal verskyn" (Mt 24:30) niks anders sal wees sal weesnie -as juis die kruis van Christus nie (Chrysostomos, In Matthaeum, PG 57:698).

\section{Literatuurverwysings}

Barkhuizen, J H 2001a. Proclus bishop of Constantinople: Homilies on the life of Christ, Brisbane: Australian Catholic University.

Barkhuizen, J H 2001b. A short note on the 'cross' as symbol in the homilies of Proclus of Constantinople. Acta Patristica et Byzantina 12, 24-29.

Finney, P C 1997. s v Cross, in Ferguson, E (ed), Encyclopedia of Early Christianity. New York: Garland Publishing.

Karpozilos, A \& Cutler, A, 1991. The cross in everyday life, in The Oxford Dictionary of Byzantium. Oxford: Oxford University Press.

Podskalsky, G P 1991. s v Cross, in The Oxford Dictionary of Byzantium. Oxford: Oxford University Press.

Reijners, G Q 1965. The terminology of the Holy Cross in early Christian Literature, Nijmegen: Dekker \& Van de Vegt.

Reijners, G Q 1973. Cross symbolism in Hippolytus, in Mélanges Christine Mohrmann, 13-24. Utrecht: Spectrum.

Taft, R F \& Karpozilos, A 1991. s v Cross, Cult of the, in The Oxford Dictionary of Byzantium. Oxford: Oxford University Press.

Young, F M 1987. Allegory and atonement. Australian Biblical Review 35, 107-114.

Young, F M 1997. s v Atonement, in Ferguson, E (ed), Encyclopedia of Early Christianity. New York: Garland Publishing. 